\title{
Ulnar Nerve Entrapment in Guyon's Canal Due to Recurrent Carpal Tunnel Syndrome: Case Report
}

\author{
Rekürren Karpal Tünel Sendromuna Bağh Guyon Kanalında Ulnar Sinir \\ Tuzaklanması: Olgu Sunumu
}

Ozgur OZDEMIR, Tarkan CALISANELLER, Salih GULSEN, Hakan CANER

Baskent University, Faculty of Medicine, Department of Neurosurgery, Ankara, Turkey

Correspondence address: Ozgur OZDEMIR / E-mail: ozgurhozdemir@yahoo.com

\begin{abstract}
Guyon's canal syndrome is a compression neuropathy of the ulnar nerve entrapment at the wrist. Compression of the ulnar nerve at the wrist by a ganglion, lipomas, diseases of the ulnar artery, fractures of the hamate and trauma are common etiologcal factors. Unlike Guyon's canal syndrome, carpal tunnel syndrome (CTS) is the most common nerve entrapment of the upper extremity. Although, open (OCTR) or endoscopic carpal tunnel release (ECTR) is highly effective in relieving pain, failure with carpal tunnel release is seldom seen. In this paper, we presented a patient with ulnar nerve entrapment associated with recurrent CTS and discussed the possible pathomechanism with a review of current literature.
\end{abstract}

KEYWORDS: Guyon's canal, Recurrent carpal tunnel syndrome, Ulnar nerve, Median nerve

öz

Guyon kanalı sendromu ulnar, sinirin el bileğindeki basısına bağlı olarak gelişen bir tuzak nöropatisidir. Bası sebepleri arasında ganglion, lipom, ulnar arter hastalıkları, hamat kırıkları ve travma yaygın olarak bulunur. Karpal tünel sendromu ise üst ekstremitelerin en sık izlenen sinir tuzaklanmasıdır. Açık ya da endoskopik olarak yapılan karpal tünel serbestleştirilmesi ağrıyı azaltmada oldukça etkili olsa da, serbestleştirmede başarısız sonuçlar da nadir olarak izlenmektedir. Bu yazıda, rekürren karpal tünel sendromu ile birlikte gelişen bir ulnar sinir tuzaklanmasını sunduk ve olası patomekanizmayı literatür eşliğinde tartıştık.

ANAHTAR SÖZCÜKLER: Guyon kanalı, Rekürren karpal tünel sendromu, Ulnar sinir, Median sinir

\section{INTRODUCTION}

Guyon's canal syndrome is a compression neuropathy of the ulnar nerve entrapment at the wrist or hand that can cause motor, sensory or combined motor and sensory loss depending on the localization of entrapment along the channel (1). The most common etiological factor is the compression of the ulnar nerve at the wrist by a ganglion. However, other conditions such as anomalous musculotendinous arches, lipomas, diseases of the ulnar artery, fractures of the hamate, direct trauma to the ulnar side of the hand, and activities with prolonged wrist hyperextension and occupational trauma may compress the ulnar nerve at wrist $(4,7,15,16)$.

Unlike Guyon's canal syndrome compression of the median nerve at the wrist or carpal tunnel syndrome (CTS) is the most common nerve entrapment of the upper extremity with a prevalence of $5-16 \%$ in the general population (17). 400,000 and 500,000 carpal tunnel surgical release procedures are performed annually in the United States (13). In experienced hands, open (OCTR) or endoscopic carpal tunnel release
(ECTR) is highly effective in relieving pain in more than $95 \%$ of patients with a complication rate of 2,6-3\% (11).

Most reported complications after carpal tunnel release is persistence or recurrence of symptoms (6). Neurological complications involving the ulnar nerve are rare but mostly associated with endoscopic carpal tunnel release (8).

In this article, we reported a patient with delayed occurrence of a ulnar nerve entrapment at the wrist following an open carpal tunnel release. We also discussed the possible underlying mechanisms with current literature.

\section{CASE REPORT}

A 50-year-old right-handed woman was admitted with right hand weakness and progressive clawing of her ulnar fingers that began 4 months after open carpal tunnel release of the right hand. She underwent surgery based on the clinical findings and routine electromyographic studies (EMG) that were consistent with median neuropathy at the wrist. Ulnar motor and sensory nerve conduction studies were normal. In the postoperative period, her symptoms almost completely 
recovered. She noticed a numbness in the $4^{\text {th }}$ and $5^{\text {th }}$ fingers and progressive clawing of the $4^{\text {th }}$ and $5^{\text {th }}$ fingers later on. She had difficulty in holding knife and doing homework. On neurological examination 4 months after the right carpal tunnel surgery, slight claw deformity of $4^{\text {th }}$ and $5^{\text {th }}$ finger was observed. The sensation was impaired in ulnar and in the median aspect of right hand. In addition, there was obvious weakness of the right dorsal interossei and flexor digiti minimi muscles. A new electromyographic study revealed prolongation of distal motor and sensory latencies of median and ulnar nerves of the right hand. A diagnosis of recurrent carpal tunnel syndrome and ulnar neuropathy at Guyon's canal was accordingly made.

A single palmar incision was used for exploration of Guyon's canal and Carpal tunnel's contents. Both median and ulnar nerves were intact but the ulnar nerve was impinged. The median nerve was dissected free from the tendons and fibrosis at the wrist and decompressed. The ulnar nerve and artery were decompressed also and neurolysis of median and ulnar nerves was performed (Figure 1). The postoperative period was uneventful. Six months after surgery, she had mild claw deformity and sensory impairment but improved strength in her intrinsic hand muscles.

\section{DISCUSSION}

Guyon's canal syndrome is a compression neuropathy of the ulnar nerve at the wrist or hand, which causes isolated motor, sensorial or combined loss of motor and sensorial function of the nerve (1). The 4 to $4,5 \mathrm{~cm}$ long tunnel known as Guyon's canal begins proximal to the hypothenar eminence and extends to the fibrous arch of the hypothenar muscles. The roof is composed of the palmar carpal ligament, palmaris brevis and fibrous tissue. The floor is composed of the tendons of the flexor digitorum profundus proximally, the transverse carpal ligament, and the pisohamate and pisometacarpal ligaments. The medial wall includes the flexor carpi ulnaris, the pisiform, and the abductor digiti minimi. The lateral wall is formed by the tendons of the finger flexors, transverse carpal ligament, and the hook of the hamate (Figure 2) (14). Different types of lesions cause ulnar nerve entrapment at wrist and hand including a ganglion, traumatic neuritis, ulnar artery disease and factures of carpal bones. However, other lesions such as lipomas, anomalous muscles, osteoarthritis and lesions of ulnar artery can cause ulnar nerve compression $(1,4,7,16)$.

For moderate to severe CTS, surgical division of the transverse carpal ligament either by an open approach (OCTR) or an endoscopic procedure (ECTR) is safe and highly effective in relieving pain and paresthesias in more than $95 \%$ of patients. Although division of the transverse carpal ligament (TCL) is a safe procedure, a variety of complications are reported with a rate of $2,6-3 \%(11)$.

The most common cause of failure after carpal tunnel release is persistence of the symptoms due to incomplete division of the TCL (6). On the other hand, true recurrent CTS

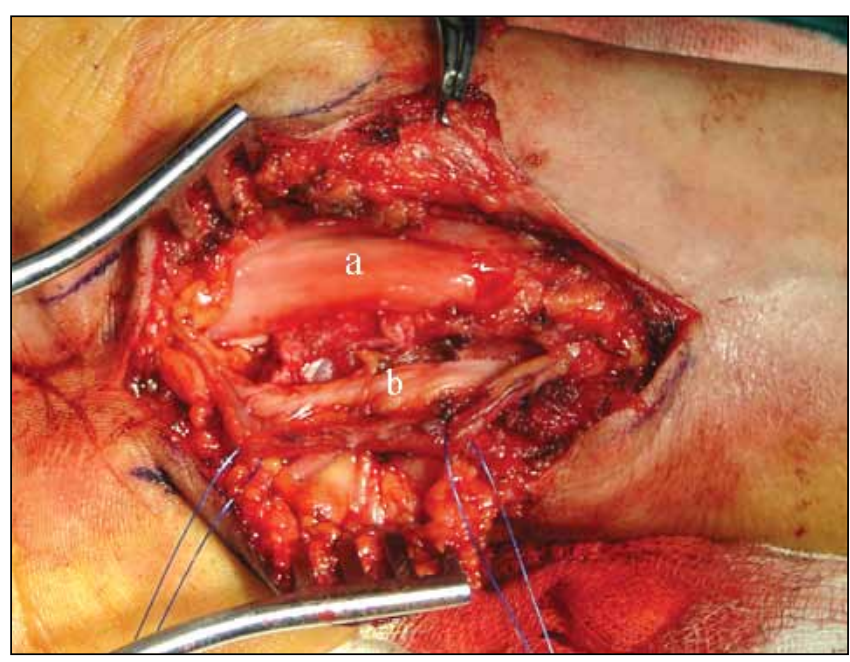

Figure 1: Intraoperative view of decompressed median nerve (a) and ulnar nerve (b). Notice the ulnar nerve dissected from ulnar vascular bundle.

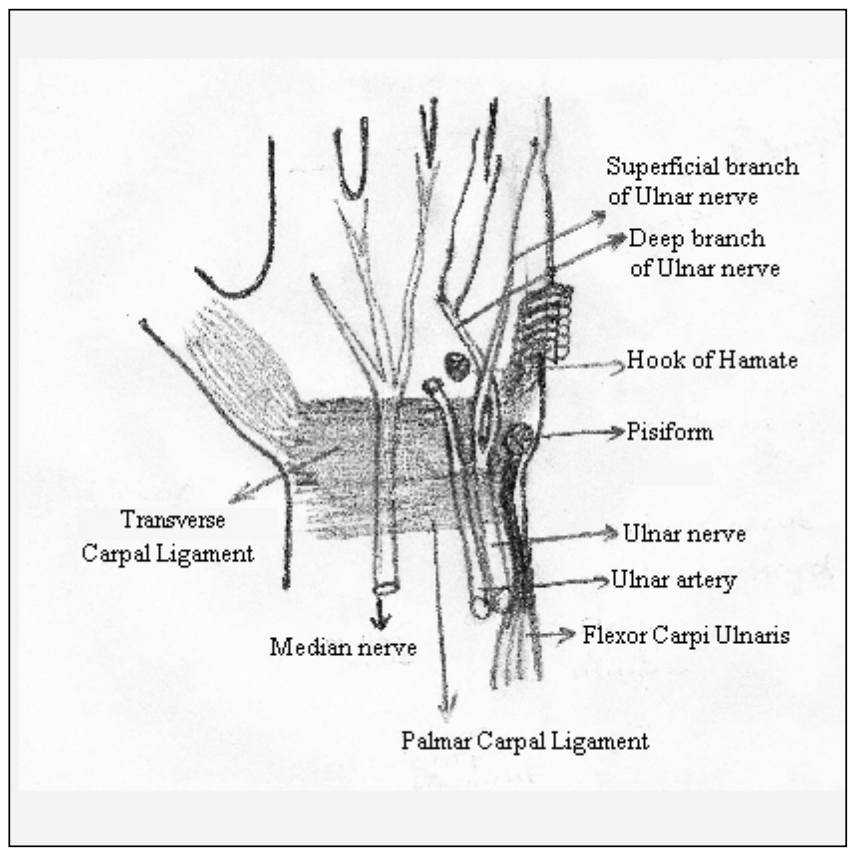

Figure 2: Schematic diagram of median nerve, ulnar nerve and their relations.

is defined as the return of the symptoms after a symptomfree period (20). True recurrence of the symptoms mostly resulted from the pathological scar formation around the median nerve, prolonged immobilization, or inadequate range of motion exercises after release of the CTS. Other new postoperative symptoms apart from the initial complaints include neurological and vascular complications, pain at the wrist, tendon abnormalities, and wound complications (19). Neurological complications of carpal tunnel surgery are frequently related to direct injury of the palmar cutaneous 
branch of the median nerve with a more radial incision. Ulnar nerve injury is most commonly associated with laceration of the ulnar nerve due to limited visibility during endoscopic release of carpal tunnel surgery. Favero et al. reported an ulnar nerve laceration at the level of Guyon's canal and resultant neuroma formation (8). Additionally, Terrono et al. reported three cases in which laceration of the deep motor branch of the ulnar nerve was not noticed at the time of surgery (18). However, in our case which underwent open CTR previously, reexploration demonstrated no laceration of the ulnar nerve.

Complications related to tendon translocation have been reported previously (2). Since transverse carpal ligament (TCL) serves as a pulley for the flexor tendons, bowstringing of the flexor tendons or displacement palmarward after division of TCL are well documented (12). This may cause entrapment of the median nerve between the cut edges of TCL and resulted in recurrence of symptoms. Braun et al. recommend placing the wrist in 10 to 15 degrees of extension in order to prevent the bowstringing the flexor tendons tunnel during the early postoperative healing phase (3). However, Bury et al. reported no beneficial effect of postoperative splinting (5). On the other hand, some authors have reported that occurrence of the concurrent ulnar nerve entrapment and CTS is not rare $(9,10)$. They suggested that high pressure in the carpal tunnel transmitted to the ulnar tunnel and caused mechanical compression due to close anatomical proximity. However, preoperative EMG study and clinical data in the current case showed normal ulnar nerve conduction and no sign of ulnar nerve entrapment. We therefore excluded concurrent median and ulnar nerve entrapment.

In conclusion, we propose a pathomechanism based on the clinical signs, intraoperative findings and EMG study where displacement of the flexor tendons induced by postoperative fibrosis resulted in recurrent CTS. The increased carpal tunnel pressure that transmitted to the Guyon's canal caused signs of ulnar neuropathy. Ulnar nerve conduction studies should therefore be performed done for correct interpretation of the possible causes of failure and/or recurrences in cases with a recurrent $\mathrm{CTS}$.

\section{REFERENCES}

1. Aguiar PH, Bor-Seng-Shu E, Gomes-Pinto $F$, Almeida- Leme RJ, Freitas AB, Martins RS, Nakagawa ES, Tedesco-Marchese AJ: Surgical management of Guyon's canal syndrome, an ulnar nerve entrapment at the wrist: Report of two cases. Arq Neuropsiquiatr 59(1):106-11, 2001

2. Amadio PC: The first carpal tunnel release? J Hand Surg (Br) 20:40-41, 1995

3. Braun RM, Rechnic M, Fowler E: Complications related to carpal tunnel release. Hand Clin 18:347-357, 2002
4. Bui-Mansfield LT, Williamson M, Wheeler DT, Johnstone F: Guyon's canal lipoma causing ulnar neuropathy. AJR Am J Roentgenol 178(6): 1458, 2002

5. Bury TF, Akelman E, Weiss AP: Prospective, randomized trial of splinting after carpal tunnel release. Ann Plast Surgery 35(1), 19-22, 1995

6. Craft RO, Duncan SF, Smith AA: Management of recurrent carpal tunnel syndrome with microneurolysis and the hypothenar fat pad flap. Hand (N Y) 2(3):85-89, 2007

7. Emel E, Guzey FK, Alatas I: Guyon's canal syndrome due to a tortuous ulnar artery: A case report. Turkish Neurosurgery 13: 107-110, 2003

8. Favero KJ, Gropper PT: Ulnar nerve laceration-a complication of carpal tunnel decompression: Case report and review of the literature. J Hand Surg (Br) 12:239 -241, 1987

9. Ginanneschi F, Milani P, Mondelli M, Dominici F, Biasella A, Rossi A: Ulnar sensory nerve impairment at the wrist in carpal tunnel syndrome. Muscle Nerve 37(2):183-189, 2008

10. Gozke E, Dortcan N, Kocer A, Cetinkaya M, Akyuz G, Us O: Ulnar nerve entrapment at wrist associated with carpal tunnel syndrome. Neurophysiol Clin 33(5):219-222, 2003

11. Jimenez DF, Gibbs SR, Clapper AT: Endoscopic treatment of carpal tunnel syndrome: A critical review. J Neurosurg 88(5):817-826, 1998

12. Kiritsis PG, Kline SC: Biomechanical changes after carpal tunnel release: A cadaveric model for comparing open, endoscopic, and step-cut lengthening techniques. J Hand Surg (Am) 20(2): 173-180, 1995

13. Palmer DH, Hanrahan LP: Social and economic costs of carpal tunnel surgery. Instr Course Lect 44:167-172, 1995

14. Rengachary SS, Arjunan K: Compression of the ulnar nerve in Guyon's Canal by a soft tissue giant cell tumor. Neurosurgery 8(3): 400-405, 1981

15. Shu N, Uchio Y, Ryoke K, Yamamoto S, Oae K, Ochi M: Atypical compression of the deep branch of the ulnar nerve in Guyon's canal by a ganglion. Case report. Scand J Plast Reconstr Surg Hand Surg 34:181-183, 2000

16. Subin GD, Mallon WJ, Urbaniak JR: Diagnosis of ganglion in Guyon's canal by magnetic resonance imaging. Hand Surg (Am) 14:640-643, 1989

17. Tanaka S, Wild DK, Seligman PJ, Behrens V, Cameron L, PutzAnderson V: The US prevalence of self-reported carpal tunnel syndrome: 1988 National Health Interview Survey data. Am J Public Health 4(11):1846-1848, 1994

18. Terrono AL, Belsky MR, Feldon PG, Nalebuff EA: Injury to the deep motor branch of the ulnar nerve during carpal tunnel release. J Hand Surg (Am) 18:1038-1040, 1993

19. Tung TH, Mackinnon SE: Secondary carpal tunnel surgery. Plast Reconstr Surg 107:1830-1843, 2001

20. Wulle C: Treatment of recurrence of the carpal tunnel syndrome. Ann Chir Main 6(3):203-209, 1987 